УДК 347.77:330.1

Задорожнюк Н.О., к.е.н., доцент

Zadorozhniuk N. Candidate of Economic Sciences, Associate Professor https://orcid.org/ 0000-0001-9708-7242

Щьокіна С.Ю. к.е.н., доцент

Shchokina E. Candidate of Economic Sciences, Associate Professor https://orcid.org/0000-0002-8442-0250

Швєд М.О., студентка

Shvied M., student

https://orcid.org/ 0000-0003-1870-0892

\title{
РОЗВИТОК ВІДНОСИН У СФЕРІ ІНТЕЛЕКТУАЛЬНОЇ ВЛАСНОСТІ: АКТУАЛЬНІ ТЕНДЕНЦІї
}

\author{
Одеський національний політехнічний університет
}

\begin{abstract}
Відповідно до єдності різних аспектів відносин власності у статті визначено вплив на розвиток відносин у сфері інтелектуальної власності: економічний, правовий, соціальний, науково-технічний та психологічний. Особливу увагу у роботі приділено саме науково-технічному впливу. Визначено особливості прав інтелектуальної власності при застосуванні різноманітних технологій, таких як: діяльність у мережі Інтернет; робототехніка та штучний інтелект; тривимірний (3D) друк; діяльність на майданчиках краудсорсингу та застосування технології blockchain.

Дослідження світового досвіду з ключових проблем у сфері інтелектуальної власності дозволили визначити різноманітні порушення прав цього виду власності. У цій роботі авторами запропоновано групування порушення прав у сфері інтелектуальної власності на три групи: порушення авторських та суміжних прав; порушення інтелектуальних прав на об'єкти промислової власності та порушення інтелектуальних прав власників на товарний знак. У межах кожної групи порушень розглянуто найбільш поширені види: плагіат авторського твору, контрафакція, промислове шпигунство (промисловий шпіонаж), патентний тролінг, кіберсквотинг, піратство у сфері інтелектуальної власності та діяльність «хмарних рантьє». Авторами запропоновано табличне відображення групування порушень прав у сфері інтелектуальної власності з зазначенням найбільш поширених видів порушень.

Також у статті визначено актуальні тенденції еволюції інституту охорони прав інтелектуальної власності: поширення режиму охорони прав інтелектуальної власності на нові об'єкти та нетрадиційні сфери їх застосування; спрощення процедури отримання правової охорони об'єктів інтелектуальної власності; лібералізація відносин щодо використання результатів інтелектуальної діяльності за рахунок державного бюджету або спеціальних цільових фондів; поширення міжнародного співробітництва в галузі охорони прав інтелектуальної власності.
\end{abstract}

Ключові слова: інтелектуальна власність, порушення прав власності, кіберсквотинг, хмарні рантьє, краудсорсинг, новітні технології.

\section{DEVELOPMENT OF RELATIONS IN THE FIELD OF INTELLECTUAL PROPERTY: CURRENT TRENDS}

\section{Odessa National Polytechnic University}

In accordance with the unity of various aspects of property relations, the article defines the impact on the development of relations in the field of intellectual property: economic, legal, social, scientific, technical and psychological. Special attention is paid to scientific and technical impact. The features of intellectual property rights in the application of various technologies are determined, such as: activities on the Internet; robotics and artificial intelligence; three-dimensional (3D) printing; activities on crowdsourcing sites and the use of blockchain technology.

Research of world experience on key problems in the field of intellectual property has allowed us to identify various violations of the rights of this type of property. In this paper, the authors propose grouping violations of intellectual property rights into three groups: violation of copyright and related rights; violation of intellectual rights to industrial property objects and violation of intellectual rights of trademark owners. Within each group of violations, the most common types are considered: plagiarism of the author's work, counterfeiting, 
industrial espionage (industrial espionage), patent trolling, cybersquatting, piracy in the field of intellectual property and the activities of "cloud rentiers". The authors propose a graphical representation of the grouping of violations of rights in the field of intellectual property, indicating the most common types of violations.

The article also identifies current trends in the evolution of the Institute for the protection of intellectual property rights: extending the regime for the protection of intellectual property rights to new objects and nontraditional areas of their application; simplifying the procedure for obtaining legal protection of intellectual property objects; liberalizing relations on the use of intellectual property results at the expense of the state budget or special trust funds; spreading international cooperation in the field of intellectual property rights protection.

Key words: intellectual property, property rights violations, cybersquatting, cloud rentiers, crowdsourcing, the latest technologies.

Постановка проблеми у загальному вигляді і її з важливими науковими та практичними завданнями. Актуальність дослідження обумовлена трансформацією структури власності в різних країнах з одного боку та впровадженням різноманітних інновацій у всі сфери життя. Зазначені процеси визначають ключове значення відносин у сфері інтелектуальної власності. Проте визначення специфіки та тенденцій розвитку відносин саме у сфері інтелектуальної власності $є$ відкритими питаннями. Тому безумовно важливим та актуальним на сьогодні є здійснення нових та аналіз проведених наукових досліджень щодо пошуку відповідей на означені питання.

Аналіз останніх досліджень, у яких започатковано вирішення проблеми. Серед вітчизняних науковців, які займаються дослідженням питань, пов'язаних 3 інтелектуальною власністю можна виділити: Вахонєву Т. та Семенову В., які розкривають сутність поняття права інтелектуальної власності та його складових [1-2]; Лиска П. та Ходаківського С., праці яких присвячено економіко-правовим аспектам захисту прав інтелектуальної власності, особливо у всесвітній мережі [3-4]; Фесенка Н., яка враховує закордонний досвід забезпечення державою захисту інтелектуальної власності [5]; Орлюк О., яка враховує моральний аспект у дотримання прав інтелектуальної власності [6]; Лазарєва М., який особливу увагу приділяє управлінню підготовці фахівців у сфері інтелектуальної власності [7] та ін. Не зважаючи на значну кількість публікації в означеній проблематиці, серед вчених недостатньо розкрито питання щодо розвитку сучасних відносин у сфері інтелектуальної власності.

Цілі статті. Ключовими цілями статті є: з'ясування, які аспекті власності впливають на розвиток відносин у сфері інтелектуальної власності; визначення особливостей прав інтелектуальної власності при використанні різноманітних технологій, у тому числі новітніх; розгляд найбільш поширених порушень прав інтелектуальної власності у світі.

Виклад основного матеріалу дослідження 3 повним обгрунтуванням отриманих наукових результатів. Інтелектуальна власність - це закріплені законом права на результати інтелектуальної (креативної та творчої) діяльності у різних сферах: виробничій, науковій, літературній та художній. Відповідно до єдності різних аспектів відносин власності слід визначити, що впливає на розвиток відносин у сфері інтелектуальної власності.

Економічний аспект відображає відносини між людьми з приводу привласнення об'єктів інтелектуальної власності (об'єкти авторського та суміжних прав; об'єкти науково-технічної інформації та промислової власності; засоби індивідуалізації). Економічні суб'єкти та економіка в цілому через реалізацію відповідних стратегій впливають на розвиток відносин у сфері інтелектуальної власності.

Правовий аспект відображає законодавче закріплення економічних відносин між фізичними і юридичними особами з приводу володіння, користування й розпорядження об'єктами інтелектуальної власності через систему законів і норм. Тобто законодавчі база має вплив на розвиток та захист відносин у сфері інтелектуальної власності. 


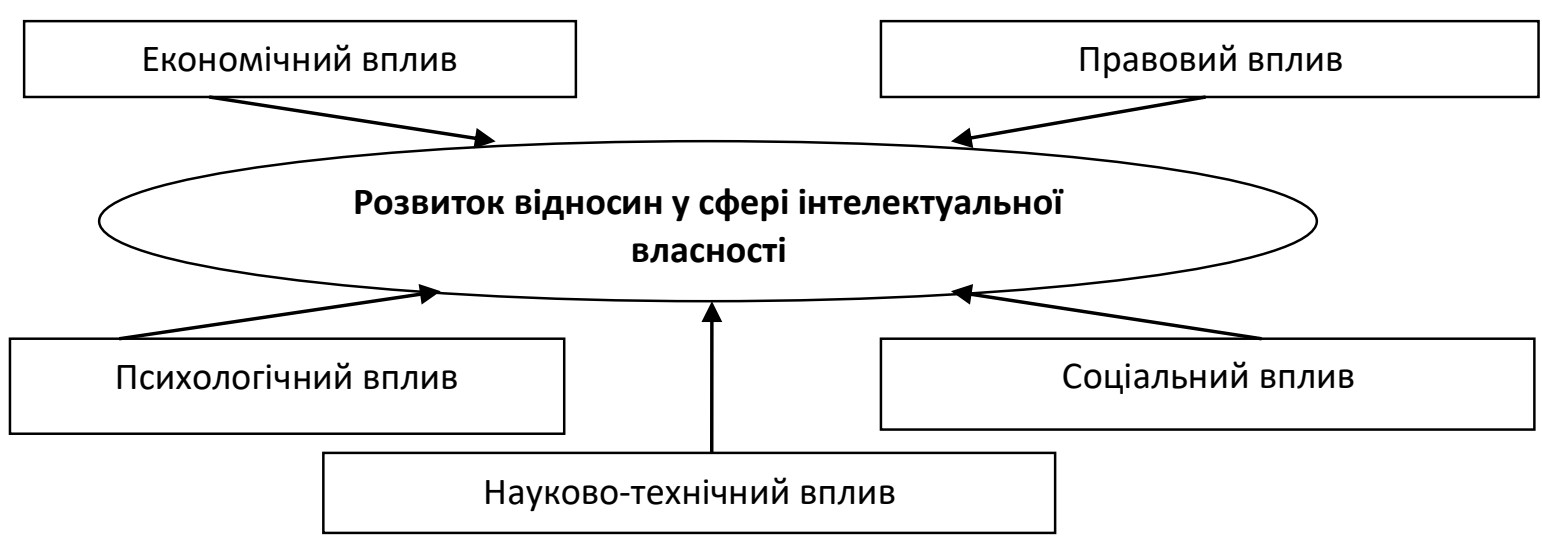

Соціальний аспект власності розкриває процес формування та розвитку певних класів, соціальних верств і груп населення та взаємодію між ними залежно від ставлення до об'єктів інтелектуальної власності [8, с. 78], а також способів отримання певної частки національного багатства.

Психологічний аспект власності виявляє індивідуально-особистісні якості людей, пов'язані 3 використанням у їхній інтелектуальної діяльності. Тобто соціальний та психологічний вплив здійснюється через те, що «соціум обирає» вектор та темп розвитку відносин у сфері інтелектуальної власності.

Науково-технічний вплив відображає інноваційний розвиток не тільки виробництва та бізнес-процес, а й впровадження різноманітних інновацій у повсякденне життя. Слід відзначити, що саме результати НТП прискорюють розвиток відносин у сфері інтелектуальної власності.

Відповідно з [9, с. 187] можна відзначити актуальні геополітичні тенденції у сфері інтелектуальної власності:

- зміщення інноваційної активності економічних суб’єктів, включаючи патентування в передових сферах розвитку технологій, в азіатські країни (Китай, Японію, Корею, Сінгапур та ін.);

- збільшення темпів розробки і виробництва інноваційних продуктів в країнах БРІКС, яке супроводжується відходом від високих стандартів захисту інтелектуальної власності та пошуком ефективної моделі регулювання, що буде відповідати інтересам національної економіки;

- розвиток регіональних систем охорони інтелектуальної власності, які на відміну від глобальних систем охоплюють меншу кількість учасників, але мають перевагу, що виражається в поєднанні загальної процедури надання охорони і національного режиму діï;

- розвиток єдиної системи патентування в рамках євразійського економічного союзу (Євразійське патентне відомство);

- політика країн БРІКС в області інтелектуальної власності для вирішення актуальних проблем в сфері соціально-економічного розвитку;

- зміна ролі Китаю та інших країн, які є джерелами дешевої робочої сили, в результаті появи нових можливостей механізації ручної праці може бути одним 3 наслідків поширення технології 3D друку.

В сучасній економічній системі спостерігається перехід від конкуренції продуктів і послуг до конкуренції на рівні бізнес-моделей, в основі яких лежать інноваційні технології та методи управління. Однією 3 найбільш популярних технологій $\epsilon$ краудсорсинг, яка передбачає передачу окремих виробничих функцій невизначеному колу осіб на підставі публічної оферти без укладення трудового договору. При цьому використовуються колективний інтелект і співпраця великої кількості людей, що потребує урахування прав та захисту інтелектуальної діяльності. 
Також широкого застосовується Blockchain (блокчейн) - технологія, створена на основі дії криптовалюти біткоін. Головна особливість, яку слід відзначити - складне технічне обгрунтування, яку можна використовувати в інтелектуальній діяльності.

НТП обумовлює необхідність визначення особливостей прав інтелектуальної власності при застосуванні різноманітних технологій, таких як: діяльність у мережі Інтернет; робототехніка та штучний інтелект; тривимірний (3D) друк; діяльність на майданчиках краудсорсингу та застосування технологіï blockchain (табл. 1).

Таблиця 1 - Особливості прав інтелектуальної власності при застосуванні різноманітних технологій

\begin{tabular}{|c|c|}
\hline Технології & Особливості прав інтелектуальної власності \\
\hline $\begin{array}{l}\text { 1. Робототехніка та } \\
\text { штучний інтелект }\end{array}$ & $\begin{array}{l}\text { Алгоритмічні рішення, покладені в основу цих пристроїв і способів - } \\
\text { це винаходи, корисні моделі, промислові зразки і об'єкти ноу-хау. } \\
\text { Інформація, яка ними генерується може бути захищена в якості } \\
\text { об'єкта суміжних прав. Алгоритм штучного інтелекту є об'єктом } \\
\text { патентування. }\end{array}$ \\
\hline $\begin{array}{l}\text { 2. Тривимірний (3D) } \\
\text { друк }\end{array}$ & $\begin{array}{l}\text { Для забезпечення захисту прав інтелектуальної власності слід } \\
\text { визначити 3D-модель відноситься до цифрової моделі. Висока } \\
\text { ймовірність порушень авторського і патентного право, а також } \\
\text { засобів індивідуалізації (товарні знаки). Програма, що застосовує } \\
\text { CAD-файл має охоронятися як літературний твір, а 3D-принтер, в } \\
\text { разі наявності в ньому унікальних елементів і технічних рішень, } \\
\text { повинен охоронятися відповідними правовими механізмами } \\
\text { інтелектуальної власності. }\end{array}$ \\
\hline 3. Краудсорсинг & $\begin{array}{l}\text { аявність низки комерційних ризиків при розкритті намірів, бізнес- } \\
\text { танів тощо. Важливо оформити договір } 3 \text { метою врегулювання } \\
\text { дносин } 3 \text { переможцем краудсорсингового проекту та захисту прав } \\
\text { телектуальної діяльності. }\end{array}$ \\
\hline 4. Blockchain & $\begin{array}{l}\text { Технологія блокчейн створювалася автономно від правової системи, } \\
\text { що ускладнює кваліфікацію правовідносин відповідно до прийнятих } \\
\text { стандартів. Проте за допомогою технології блокчейн існує } \\
\text { можливість створення єдиного реєстру правовласників і результатів } \\
\text { iнтелектуальної діяльності; забезпечення прозорості у пошуку } \\
\text { потенційних інвесторів. }\end{array}$ \\
\hline $\begin{array}{l}\text { 5. } \\
\text { мережі Інтье }\end{array}$ & $\begin{array}{l}\text { Висока ймовірність порушень авторського права та крадіжки } \\
\text { особистих даних. }\end{array}$ \\
\hline
\end{tabular}

Джерело: здійснено авторами на основі [9, с. 53-98]

Тобто розглянуті особливості прав інтелектуальної власності при використанні різноманітних технологій дозволяють врахувати можливі ризики у економічній та повсякденній діяльності, пов'язані з порушенням даного виду власності.

Важливо відзначити, що стрімкий розвиток інноваційної діяльності та активне впровадження інновацій обумовлюють поширення різних порушень щодо прав інтелектуальної власності:

- контрафакція - протизаконне виготовлення і розповсюдження екземплярів результату інтелектуальної праці (твору) без згоди правовласника;

- промислове шпигунство - протизаконне вилучення інформації, застосування якої може принести економічні вигоди;

- патентний тролінг полягає в отриманні з добросовісного виробника ліцензійних або інших платежів за використання належних тролевих патентів, що застосовуються у виробництві товарів (послуг) цього виробника;

- кіберсквотинг полягає у реєстрації, використанні та пропонуванні до продажу доменного імені із наміром отримати прибуток від паразитування на гудвілі або торговельній марці, яка належить іншій особі [7, с. 319]; 
- піратство у сфері інтелектуальної власності - використання об'єктів авторського права і суміжних прав з метою отримання комерційної вигоди без згоди правовласників;

- діяльність «хмарних рантьє» - незаконне комерційне використання хмарних даних (персоніфікованих облікових записів користувачів Інтернету або персональних даних компаній) з метою збагачення.

Авторами запропоновано наочне групування найчастіших видів порушень щодо прав інтелектуальної власності (таблиця 2).

Таблиця 2 Групування найчастіших видів порушень щодо прав інтелектуальної власності

\begin{tabular}{|c|c|c|}
\hline \multicolumn{3}{|c|}{ Види порушень щодо прав інтелектуальної власності } \\
\hline 1. Авторських прав & 2. Суміжних прав & 3. Промислової власності \\
\hline 1.1. Плагіат & 2.1. Плагіат & 3.1. Контрафакція \\
\hline $\begin{array}{l}\text { 1.2. Піратство у сфері } \\
\text { інтелектуальної } \\
\text { власності }\end{array}$ & $\begin{array}{l}\text { 2.2. Піратство у сфері } \\
\text { інтелектуальної власності }\end{array}$ & 3.2. Промислове шпигунство \\
\hline 1.3. Кіберсквотинг & 2.3. Кіберсквотинг & Кіберсквотинг \\
\hline $\begin{array}{l}\text { 1.4. Діяльність «хмарних } \\
\text { рантьє» }\end{array}$ & $\begin{array}{l}\text { 2.4. Діяльність «хмарних } \\
\text { рантьє» }\end{array}$ & $\begin{array}{l}\text { 3.3. Діяльність «хмарних } \\
\text { рантьє» }\end{array}$ \\
\hline & & 3.4. Патентний тролінг \\
\hline
\end{tabular}

Джерело: згруповано авторами на основі [8, с. 78]

Висновки. Таким чином, у роботі відображені актуальні геополітичні тенденції у сфері інтелектуальної власності; визначені особливості прав інтелектуальної власності при використанні сучасних технологій; згруповані найпоширені види порушень щодо прав інтелектуальної власності. Отже, всі поставлені у роботі завдання були вирішені. В подальших дослідженнях планується розглянути міжнародний досвід щодо регулювання відносин власності.

\section{Список бібліографічного опису:}

1. Вахонєва Т. Поняття права інтелектуальної власності та його складові. Теорія і практика інтелектуальноі власності. 2015. № 6. С. 24-32.

2. Семенова В.Г. Дослідження сутності інтелектуальної власності в сучасних економічних умовах. Технологический аудит и резервы производства. 2015. № 6 (5). С. 74-77.

3. Лиска П.О. Захист прав інтелектуальної власності у всесвітній мережі. Молодий вчений. 2017. № 11. С. 901-907.

4. Ходаківський С.І., Якобчук В.П., Литвинчук І.Л. Інтелектуальна власність: економіко-правові аспекти: підручник:

3-те вид. Київ, 2017. 504 с.

5. Фесенко Н. С. Закордонний досвід забезпечення державою захисту інтелектуальної власності. Актуальні проблеми державного управління. 2016. № 2. С. 179-183.

6. Орлюк О. П. Дотримання прав інтелектуальної власності як моральна основа соціального прогресу. Альманах права. 2016. № 7. С. 33-37.

7. Лазарєв М. І. и др. Управління підготовкою фахівців у сфері інтелектуальної власності: трансформації на сучасному етапі. Актуальні проблеми державного управління. 2017. № 1. С. 113-120.

8. Забарна Е.М., Козакова О.М., Задорожнюк Н.О. та ін. Економічна теорія: закономірності, практика та сучасність: підручник. Херсон: ОЛДІ-ПЛЮС, 2020. -412 с.

9. Ахмедов Г.А., Войниканис Е.А. и др. Основные тенденции развития права интеллектуальной собственности в современном мире, в том числе новые объекты интеллектуальных прав и глобальная защита. 2017. URL: https://www.rvc.ru/upload/iblock/85d/Trends_in_Intellectual_Property.pdf (дата звернення 22.09.2020).

\section{References:}

1. Vakhonieva T. Poniattia prava intelektualnoi vlasnosti ta yoho skladovi. Teoriia i praktyka intelektualnoi vlasnosti, 2015, no. 6, pp. 24-32 [in Ukrainian]

2. Semenova V.H. Doslidzhennia sutnosti intelektualnoi vlasnosti v suchasnykh ekonomichnykh umovakh. Tekhnolohycheskyi audyt y rezervы proyzvodstva, 2015, no. 6 (5), pp. 74-77 [in Ukrainian]

3. Lyska P.O. Zakhyst prav intelektualnoi vlasnosti u vsesvitnii merezhi. Molodyi vchenyi, 2017, no. 11, pp. $901-907$ [in Ukrainian]

4. Khodakivskyi Ye.I., Yakobchuk V.P., Lytvynchuk I.L. Intelektualna vlasnist: ekonomiko-pravovi aspekty: pidruchnyk: 3tie vyd. Kyiv, 2017. 504 p. [in Ukrainian]

5. Fesenko N.S. Zakordonnyi dosvid zabezpechennia derzhavoiu zakhystu intelektualnoi vlasnosti. Aktualni problemy derzhavnoho upravlinnia, 2016, no. 2, pp. 179-183 [in Ukrainian]

6. Orliuk O.P. Dotrymannia prav intelektualnoi vlasnosti yak moralna osnova sotsialnoho prohresu. Almanakh prava, 2016, no. 7, pp. 33-37 [in Ukrainian] 
7. Lazariev M.I. y dr. Upravlinnia pidhotovkoiu fakhivtsiv u sferi intelektualnoi vlasnosti: transformatsii na suchasnomu etapi. Aktualni problemy derzhavnoho upravlinnia, 2017, no. 1, pp. 113-120 [in Ukrainian]

8. Zabarna E.M., Kozakova O.M., Zadorozhniuk N.O. ta in. Ekonomichna teoriia: zakonomirnosti, praktyka ta suchasnist: pidruchnyk. Kherson: OLDI-PLIuS, 2020. 412 p. [in Ukrainian]

9. Axmedov G.A., Vojnikanis E.A. i dr. Osnovnye tendencii razvitiya prava intellektual'noj sobstvennosti v sovremennom mire, $\mathrm{v}$ tom chisle novye ob"ekty intellektual'nyx prav i global'naya zashhita. 2017. Available at: https://www.rvc.ru/upload/iblock/85d/Trends_in_Intellectual_Property.pdf. (accessed 22.09.2020) [In Russian]

Дата подання публікації 11.11.2020 p.

\title{
УДК 336.02:658.1
}

Купира M.I., к.е.н., доцент Kupyra M. Candidate of Economic Sciences, Associate Professor https://orcid.org/0000-0002-8279-7628

Колтунович О.В., магістр, Сокол Х.Я. , студент

Koltunovych O. Master Sokol H.Ya, Student

\section{ФІНАНСОВИЙ ПОТЕНЦІАЛ ПІДПРИЕМСТВА: ФОРМУВАННЯ ТА ДЕТЕРМІНАНТИ НАРОЩЕННЯ}

\author{
Луиьький національний технічний університет
}

У статті проведено розбір ключових характеристик ресурсного та результативного підходів в напрямку визначення фінансового потенціалу. Визначено фінансовий потенціал як систему фінансових можливостей здатних трансформувати наявні ресурси у векторний процес розвитку через максимізацію та мультиплікатор капіталізації прибутковості.

Згруповано в систему фактори впливу на рівень фінансового потенціалу, які потрібно системно перетворювати в потенційні можливості. Визначено такими факторами фінансову стійкість, ефективність менеджменту активами, мультиплікатор капіталу, вектор кредитоспроможності, інноваційний вектор, інвестиційний вектор, вектор менеджменту, що точково створюють проблеми та породжують дисбаланс фінансово-економічного розвитку.

Сформовано синергетичну пряму складників фінансового потенціалу в процесі фінансовогосподарської діяльності через ефективність та доведено поетапність алгоритму роботи в частині структуризації власних та позикових фінансових ресурсів через якість аналіз, планування, контроль i гарантування в підсумку фінансової стійкості та фінансової забезпеченості.

Запропоновано структуризацію компонентів та складників фінансового потенціалу через рух і розвиток в напрямку капіталізації та максимізації.

Розроблено вектор забезпечення формування High-level фінансового потенціалу в напрямку фінансової стабільності включаючи компоненти: управлінський, фінансово-економічний, майновий, архітектурний, інтелектуальний. Тому, важливим кроком в напрямку формування фінансового потенціалу та пошуку детермінантів його нарощення ефективно генерувати саме архітектурний та інтелектуальний компоненти. Заданий алгоритм буде працювати через самофінансування та самонаповнення, 3 врахуванням мотиваційної складової кадрового потенціалу до результативної та продуктивної роботи.

Ключові слова: фінансовий потенціал, фінансова стабільність, фінансова стійкість, ефективність, асиметрії, синергія, детермінанти нарощення

\section{FINANCIAL POTENTIAL OF THE ENTERPRISE: FORMATION AND DETERMINANTS OF INCREASE}

\section{Lutsk National Technical University}

The analysis of key characteristics of resource and effective approaches in the direction of definition of financial potential carried out in the article. Financial potential defined as a system of financial opportunities capable 